\title{
腎血管筋脂肪腫の治療法選択についての検討
}

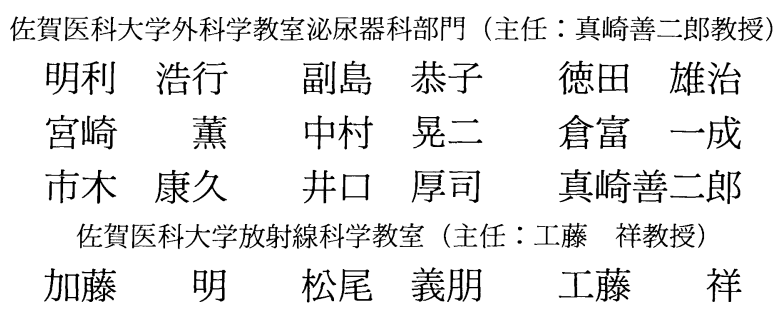

\section{THE MANAGEMENT SELECTION OF RENAL ANGIOMYOLIPOMA}

\author{
Hiroyuki Meiri, Kyoko Soejima, Yuji Tokuda, Kaoru Miyazaki, \\ Koji Nakamura, Kazunari Kuratomo, Yasuhisa Ichigi, \\ Atsushi Iguchi and Zenjiro Masaki \\ Division of Urology, Department of Surgery, Saga Medical School \\ (Director: Prof. Zenjiro Masaki) \\ Akira Kato, Yoshitomo Matsuo and Sho Kudo \\ Department of Radiology, Saga Medical School \\ (Director: Prof. Sho Kudo)
}

(Background) Nephron-sparing surgery is ideal in the treatment of renal angiomyolipoma (AML). But, in fact, ocasional cases are found in post-ruptured AML and/or in bilateral multiple AMLs, that is seen in tuberous sclerosis. And we cannot perform nephron sparing surgery so easily. We proposed the treatment selection in such complicated AML.

(Methods) We experienced 10 cases (12 kidneys) for about ten years, and studied our treatment selection and prognosis on each cases retrospectively.

(Results) Of the 5 kidneys with AML less than $4 \mathrm{~cm}$ in diameter, 4 have not encountered with rupture. Of the 7 kidneys with AML more than $4 \mathrm{~cm}$ in diameter, 4 kidneys had rupture. Of the 3 kidneys unruptured AML more than $4 \mathrm{~cm}$ in diameter, 2 kidneys were treated by enucleation and we performed preventive embolization for rupture in residual one kidney. The patients was suffered from tuberuos sclerosis, and she had bilateral multiple AMLs. Of the 4 kidneys with ruptured AML, 2 kidneys were treated by enucleation, and the other 2 kidneys were entirely resected. We succeeded enucleation in 2 of 4 kidneys with ruptured complicated AML. In those cases, we did long term watching after rupture and in-situ perfusion technique at the operation.

(Conclusions) Active treatment of AML, that is more than $4 \mathrm{~cm}$ in diameter, migth be recommended. Because most of those will be ruptured. The ideal treatment, nephron-sparing surgery is difficult in complicated situation, such as after rupture and bilateral multiple AMLs. In our opinion, the point of success of nephron-sparing surgery migth be long term watching after rupture and in-situ perfusion technique at the operation.

Key word: Renal angiomyolipoma (AML), Embolization, Nephron-sparing surgery

要旨：(背景と目的) 腎血管筋脂肪腫（AML）の治療として，腎保存手術は理想的である。しかし，実 際には破裂例や, 両側, 多発性の場合など, 腎保存手術が難しいことも多い.そのような治療困難な AML に対する治療法選択についての我々の考えを述べた.

(対象と方法) 我々が過去10年間に経験した10例（12腎）について, 我々の選択した治療法と予後につ 
いて検討した.

(結果) AML の径が $4 \mathrm{~cm}$ 以下の 5 腎では，うち 4 腎で破裂を見なかった。径 $4 \mathrm{~cm}$ 以上の AML は 7 腎 あったが，そのうちの 4 腎で破裂を見た。破裂していない径 $4 \mathrm{~cm}$ 以上の AML は 3 腎であり, うち 2 腎 には核出術を行い, あとの 1 腎に対しては，予防的塞栓術を施行した。その患者は, 多発性硬化症で, 両側，多発性にAML をもつ患者であった。破裂した AML は 4 腎あり，2 腎において核出術を行った が，残りの 2 腎は腎摘出術となった。我々が，核出術を行い得た 2 腎は，破裂後に長い観察期間をおい て手術したものと, 手術時に in-situ 潅流を用いたものであった.

(結論)径が $4 \mathrm{~cm}$ 以上の AML は, やはりその大半は将来破裂を来す可能性が高いと思われるので, 積 極的に治療したほうがよいであろう. 破裂後や両側, 多発性の場合でも腎保存手術に成功するポイント は, 破裂後は, 長い期間をおいて手術を行うことと, 手術時のin-situ 潅流にあるのではないかと考えて いる.

キーワード：腎血管筋脂肪腫 $(\mathrm{AML})$ ，塞栓術，腎保存手術

\section{緒言}

腎血管筋脂肪腫 $(\mathrm{AML})$ は，突然破裂をきたし生命 に危険が及ぶことも稀ではないが，本来良性腫瘍であ り，その治療法の選択に苦慮することが多い. Oester-

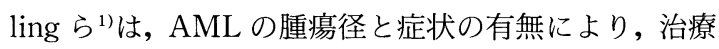
方針を区別しているが，実際の診療上は，結節性硬化 症患者のように, 腫瘍が両側多発性にみられる場合は どうすればよいのか, また, 腫瘍破裂後の手術はかな り困難なことが予想されるがどうしたらよいのか等, 治療方針の決定に苦慮することが少なくない. 現在ま でに我々は，本症を10例（12腎）経験したが，上記の 問題点を多く含んだ症例が多かったので，その治療方 針の決定方法について検討し, 以下に報告する.

\section{対象と方法}

1981年 4 月から 1992 年 10 月までの過去 12 年間に, 当 院で経験した腎血管筋脂肪腫 (AML) 10例12腎を対象 とした。各症例について症状の有無, 腫瘍径, 治療法 を Table 1 にまとめて示したが, 症例 5 と症例 7 の 2 例は結節性硬化症患者であり, 腫瘍は両側多発性に存 在したため, それぞれの腎について分けて示した。年 齢は19歳から68歳, 平均 40.8 歳で, 性別は男性 3 例, 女性 7 例であった。これらの症例を基に，腫瘍のサイ ズ別の破裂の有無, 治療法の選択について検討した。 塞栓術や手術等, 積極的療法を施行した 8 腎に対して は, その状況と治療の時期, 必然性, および成績につ いて検討した。

\section{結 果}

腫瘍径が $4 \mathrm{~cm}$ 末満であった腎 No. 1から 5 までの 5 腎に扔いては, 腎細胞癌の術前診断で腎摘出術を 行った腎 No. 4を除き，いずれも経過観察とした.それ ら 4 腎では平均 84 カ月の経過観察期間中，いずれも腫
瘍径の増大および破裂はみていない.

腫䬗径が $4 \mathrm{~cm}$ 以上あったものが, 腎 No. 6から 12 ま での 7 腎である。そのうちの 4 腎，半数以上が破裂を 来していた。

破裂を来した 4 腎のうち， 2 腎には出血のコント ロールの目的で，まず経皮的塞栓術を行った（腎 No. 9，12）。破裂直後の出血は塞栓術で良好にコントロー ルすることができたが，その後も腫場は大きいままで 残存しているため, これら 2 腎に対しては塞栓術後に 手術療法を行った。腎No.12では受診時(破裂直後) のCT に示す如く（Fig. 1A)，左腎実質内に大きな血

Table 1 症例のまとめ

\begin{tabular}{|c|c|c|c|c|}
\hline 腎 No. & 症例 No. & 症状 & 腫瘍径 (mm) & 治療 \\
\hline 1 & 1 & なし & 15 & 経過観察 \\
\hline 2 & 2 & なし & 18 & 経過観察 \\
\hline 3 & 3 & なし & 23 & 経過観察 \\
\hline 4 & 4 & なし & 30 & 腎摘出術 \\
\hline 5 & 5 & なし & $30,10 \times 4$ ケ & 経過観察 \\
\hline 6 & 6 & 血尿 & $(40)$ & 腎摘出術 \\
\hline 7 & 7 & なし & $40,20,15$ & 塞栓術 \\
\hline 8 & 5 & なし & $55,55,50$ & 核出術 \\
\hline 9 & 8 & 血尿 & $(60)$ & 塞栓術 $\rightarrow$ 核出術 \\
\hline 10 & 9 & なし & 80 & 核出術 \\
\hline 11 & 7 & 血尿 & $(90), 30$ & 核出術 \\
\hline 12 & 10 & 血尿 & $(100)$ & 塞栓術 $\rightarrow$ 腎摘出術 \\
\hline
\end{tabular}

破裂したものの径は, 血腫の大きさを含んでおり（）で囲 んでいる。

また, 症例 5 と 7 は, 結節性硬化症であり, 腫瘍は両側性に あったため, 特に症例 No.を太字で示した. 


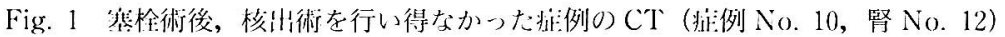

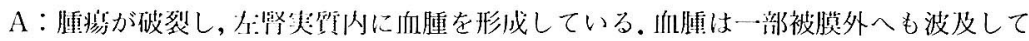

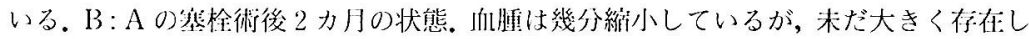
ている。
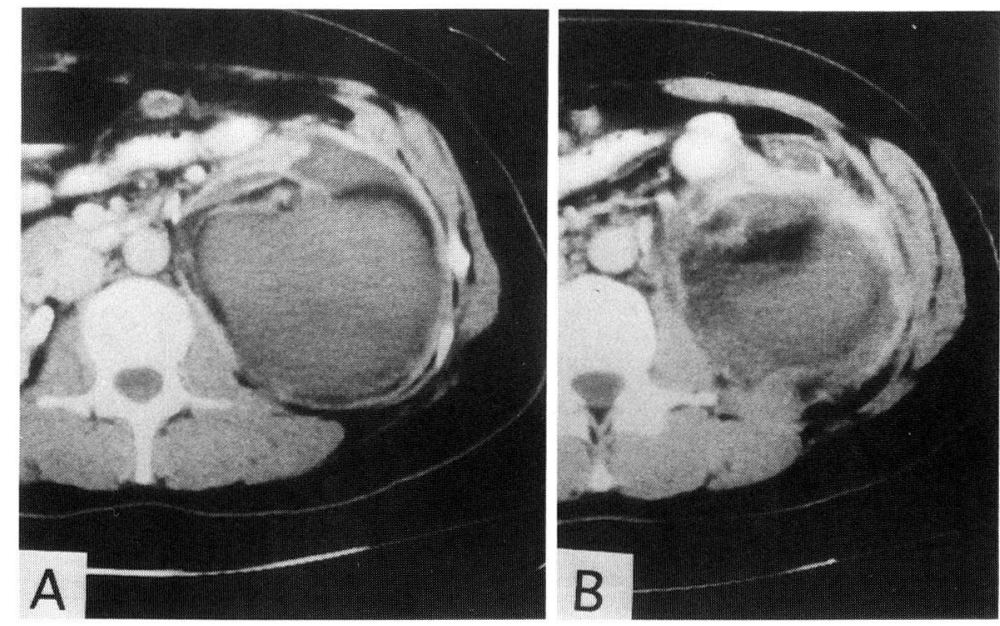

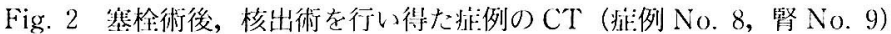

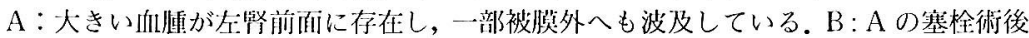
10 力月の状態. I血朠は消失しているが，比較的大きい狱変が残存している.
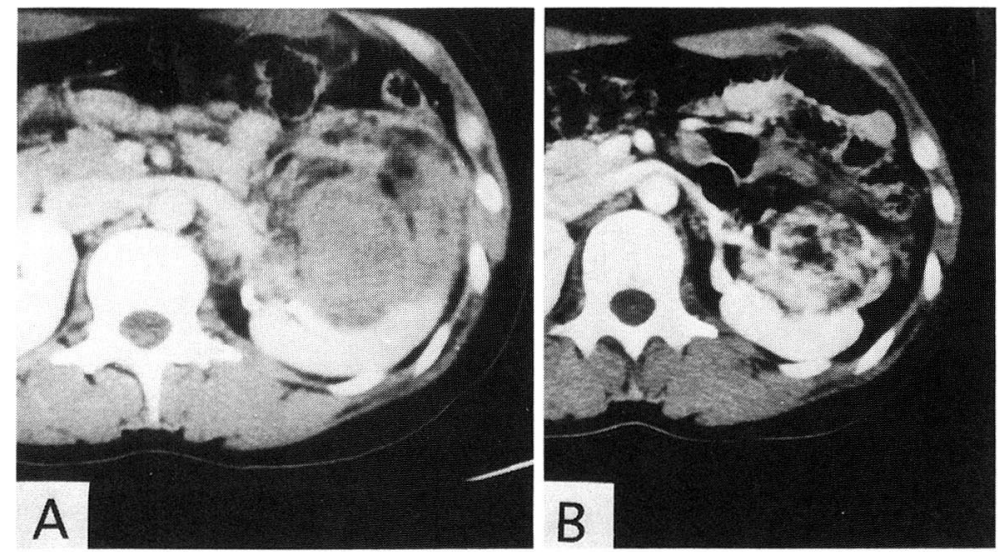

腫が形成され，一部被膜外へも波及している。これに 対し，塞栓術から 2 力月後に腫侅核出術を行扔うとし たが，血腫を含めた腫溜は腎荠部の前面を蕧うように 存在し，かつ腸管との捻着がひどく（Fig. 1B)，結局 腎摘出術とならざるを得なかった。腎No.9でも,破裂 直後にはかなり大きな折腫が存在したが(Fig. 2A), 塞栓術後約 10 力間の経過を経たのちでは血腫は消失 していた（Fig．2B）。この時点で手術を行ったが，こ ちらは ice slushによる局所冷却法を用い, 腄瘍核出術 を行い，良好な結果を得た。
破裂を来したが，塞栓術を行わず手術を行ったもの は2 腎ある(腎No.6，11)。腎N No.6は腫陽核出術を 行う予定で，術前に血管造影を行ったところ，血管内 膜損傷を起こし，腎梗塞の状態となったため，腎摘出 術となったものである。腎No.11（症例 7) は結節性

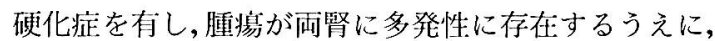
かつ在腎の破裂をみた症例である。Fig. 3A に示すよ うに, CT上腫湯が破裂し, 巨大な仮性動脈瘤を形成し ている。舆栓術も考虑したが， $39^{\circ} \mathrm{C}$ 台の発熱があり， 向液検榃上も, CRP が 32 と炎症の徴候もあったため, 
Fig. 3A in-situ灌流下に核出術を行った破裂した AML (症例 No. 7, 腎No.11)：腫湟が破裂し，大 きな血腫 (矢印) を形成している。また，血腫の中 には巨大な動脈瘤が存在している。

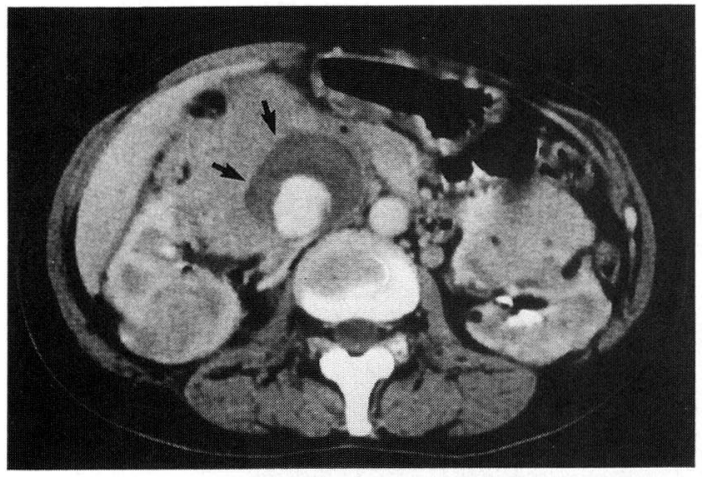

Fig. 3B in-situ灌流下に核出術を行った破裂した AML 症例O)術後 CT (症例 No. 7, 腎 No. 11)：不 腎の腎実質は充分に保たれている。左散には塞栓術 のためのクリップが認められる。

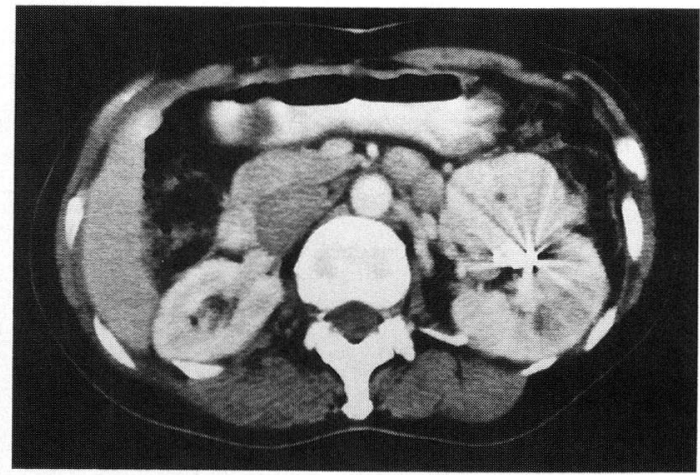

Fig. 4 破裂予防の目的で，塞栓術を行った症例（症例 No. 7, 腎 No. 7) A：結節性硬化症症例における血管造影所見，矢印の部分に多発する動脈瘤がみられ る. B : 矢印の部 ( 2 力所) に, 白金製 microcoil による塞栓術を行った. 塞栓術直後 の写真であるが, 動脈瘤像は消失している。
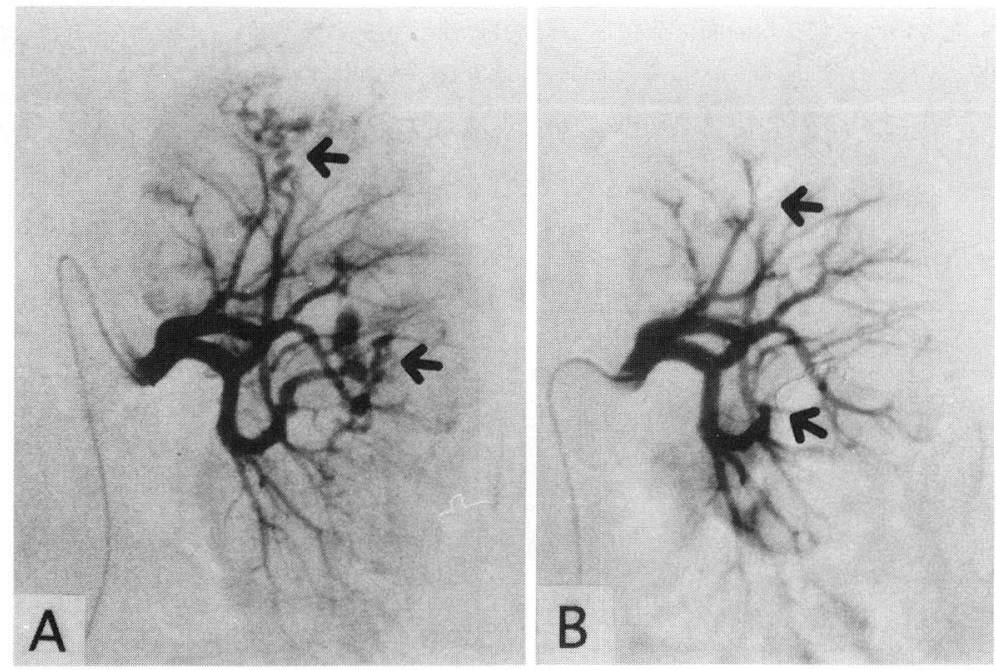

塞栓術は施行せず，in situ 灌流下に腫瘍核出術を行っ た ・すなわち, 腫湯の栄養血管である腎動脈の lower segment artery を切断，そこよりカテーテルを逆行性 に近位に向かって挿入し, 腎主幹動静脈をクランプ, ユーロコリンズ液にて灌流しながら腫陽核出術を行っ た. 阻血時間120分であったが，術後腎機能も良好に保 たれており，CT上も充分に腎実質は残っている(Fig. 3B).

腫湯径が $4 \mathrm{~cm}$ 以上あるが，破裂を来していないもの は 3 腎あった（腎No.7,8，10)。腎 No. 7 (症例 7 )
は，既に述べた如く結節性硬化症患者で，腫瘍が両側， 多発性に存在し，かつその対側腎（腎No.11）は既に 手術を受けており，今後こちらに破裂が起これば，腎 保存が困難になることが予想されるため，非破裂では あったが，予防的に白金製 microcoilによる経皮的塞 栓術を行った，腫富は残存しているが動脈瘤は消失， その後, 約 1 年間臨床的に無症状で，破裂をみずに経 過している(Fig. 4A，Fig. 4B)。 なお，本症例は高度 の肺のブラ形成があり，破裂を来していた右側婜の手 術が精一杯であり，2度目の手術を避けたいことも 
あって, 塞栓術を行った。腎 No. 8 (症例 5 ) は結節性 硬化症患者で, 腫瘍が両側, 多発性に存在していたた め,また腎 No. 10 は腫瘍径 $8 \mathrm{~cm}$ と大きかったため, ど ちらも in situ 灌流法を用い, 予防的に腫瘍核出術を 行った.

\section{考察}

腎 AML は血管組織, 平滑筋組織, 脂肪組織が様久 な割合で混在する，本来は良性の腫瘍である。しかし， 腫瘍内の動脈瘤が突然破裂し, 多量に出血すると, 生 命に危険が及ぶことも多く, また, 結節性硬化症患者 には，腎 AML が約40\%から $80 \%$ という高い割合で合 併し ${ }^{3) 4)}$ ，その場合には両側，多発性に腫瘍が発生する ことが多いことが知られている。

このような性質をもつ腎 AMLに対する治療方針と して, Oesterling ら は1986年に腎 AML 症例602例を 検討し，腫瘍径と症状の有無により治療方針を分け， 以下のように提唱している．1）腫場径が $4 \mathrm{~cm}$ 以上で 症状のある場合は，まず血管造影で腫瘍の評価を行い， もしできるならば選択的腎動脈塞栓術を行う。また， 手術を行う場合にも，腎部分切除術や腫湯核出術のよ うな腎保存的手術を行うべきで，腎摘出術は，コント ロールできない生命を脅かすような出血があったり， 腫瘍が腎臓のほぼ全体を占めているような場合に限 る.2）腫瘍径が $4 \mathrm{~cm}$ 以上で無症状の場合は，6力月毎 にCT, 超音波検査で経過観察を行い, 腫場径の著明な 増大があったり, 症状がでてきた場合には1)に準じる。 3）腫瘍径が $4 \mathrm{~cm}$ 末満で, 症状のある場合, 症状が続い たり悪化したりするときには1）に準じるが, 症状が消 失した場合には 6 力月毎の CT, 超音波検査による経 過観察を行う。4）腫瘍径が $4 \mathrm{~cm}$ 末満で無症状の場合 は 1 年毎の CT, 超音波検査による経過観察を行う。こ の Oesterling らの治療方針に原則として我々も異論 はない.しかしながら, 破裂後の状態であったり, 結 節性硬化症患者で両側，多発性に腫瘍がみられること があったりするため,この Oesterling らの治療方針の みでは，実際の診療上は，治療方針を決定しにくい場 合も少なくない．また，径 $4 \mathrm{~cm}$ 以上の場合，無症状の 症状は経過をみるという見解にも，幾ばくかの疑問を 持っている. 今回の経験はこれらの問題点をいくつか 浮き彫りにできたと考えられる。

今回の我々の症例中, 腫瘍径が $4 \mathrm{~cm}$ 以上のものは 7 腎あったが，そのうちの 4 腎は破裂症例であった。実 に半数以上の症例が破裂を来しており，やはり腫瘍径 が $4 \mathrm{~cm}$ 以上の症例については, 積極的治療の対象とし
たほうがよいのではないかと思われる。実際，非破裂 の 3 腎に対しても 1 腎に塞栓術, 2 腎に腫緜核出術と, 全例積極的に治療した。木下ら ${ }^{5}$ 本邦429例中破裂症例 は63例 $14.7 \%$ であり，破裂例の $90.5 \%$ は径 $4 \mathrm{~cm}$ 以上で あったと報告しているが，これから推定してみても4 $\mathrm{cm}$ 以上の場合，破裂の危険は楽観できないものと思 われる。

腫瘍径が $4 \mathrm{~cm}$ 以上で，無症状，非破裂例に対する治 療として，核出術と塞栓術の優劣の成績を示して検討 した報告は，著者らの調べた限り，未だ見あたらない。 塞栓術は侵襲が少なく, 繰り返し施行可といった特幑 を備えているが，血行再開通の問題を含めた長期成績 が出ていない欠点があり，これに対し核出術は侵襲が 強い反面，根治性は高い特性を備えていることは容易 に推測できる。しかし，これに加え，両者のうち，い ずれを選択するかの判断にあたって考えるべきもっと も大きい要素は，腫瘍の解剖学的状態と思われる，腫 瘍の存在位置や大きさによって，核出術が困難な場合 もあろうし，逆に塞栓術が不適当な場合もあると思わ れる. 従って，個々の症例に応じて適用すべきものと 思われる。もちろん, 後述の通り，破裂症例に対する 出血コントロールの手段として, 塞栓術が優れている ことはいうまでもない.

今回, 径 $4 \mathrm{~cm}$ 以上の非破裂 2 腎に対し，腫瘍核出術 を選択したが, その理由は，1）コイルによる塞栓術で は，腫瘍そのものの縮小がみられず（破裂症例に対す る塞栓術によって確認), 手術治療がより根治的と思え たこと,2）必要に応じて, 後述の in-situ 灌流法を用い れば，腫瘍核出術そのものがそれほど困難ではないこ と，の 2 つよる. しかし，塞栓物質の工夫などによ り，塞栓療法のみで治療できなかったかといった反省 点はある。この疑問に対しては, 塞栓療法後の長期経 過観察が必要であると思われる。

無症状で，非破裂例に，塞栓術を行ったのは，結節 性硬化症合併患者に対してである。この症例の場合， 対側は破裂後の核出術後であり，非手術腎の破裂を避 けたかったことと更に手術を加えたくなかったために 塞栓術を行った。破裂後の腎 AML に対して塞栓術を 行ったという報告 ${ }^{677}$ は多いのに対し，非破裂，無症状 の腎 AMLに対して塞栓術を行ったという報告は少な

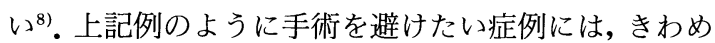
てよい適応となるものと考えられる。

我々は，腎保存手術（核出術）を行うにあたり，3 腎において，Collins 液による in situ 灌流法2)を用い 
た. 核出術に要した血流遮断は，それぞれ120分，75分， 44分であったが，阻血による腎機能障害は認めなかっ た。また，これは自家腎移植による腎保存的手術9)等に 比べ, 患者に与える侵襲も少なく, 割合容易に施行す ることができる，病変が大きかったり，あるいは多発 しているような，かなり困難な場合でも，この方法を 用いれば，今後はより積極的な腎保存手術を行うこと ができると考えられる。

次に破裂を来した症例に対し，どのように対処した らよいかという問題がある. 今回の経験では 4 例全例 に破裂後早期に血管造影を施行できたが，内膜損傷を 来した 1 例を除き, 3 例中 2 例に, 出血巣が確認でき 塞栓術を行った。他の 1 例 (Fg. 3) は，感染の合併が 疑われたため，塞栓術を行っていない。2 例とも塞栓 術後の経過は良好であった。 塞栓術が破裂後の出血コ ントロールに有効なことは，腎外傷の出血に対する優 秀な治療成績によって確認している ${ }^{10)}$ が，今回の経験 でもそれを再認識した。しかしこれが永久的治療にな りうるかという疑問に対しては，未だ確認する機会が ない. 今回, 塞栓術後手術を行ったものが 2 例あるが, 最初の例 (腎 No. 12) は, 塞栓術後 2 力月経過しても, 大きい血腫が残存したままであったため，手術に踏み 切ったが出血部と腸管との癒着が強く, 手術は困難を きわめ，結局腎摘出術とならざるを得なかった。この 経験をふまえ，2 例目は塞栓術後に社会復帰させ，10 カ月まで待機したところ, 血腫の吸収は認められたも のの，腫場は大きいままで残存していたため（腎 No. 12)，手術を行い，比較的容易に核出術を施行でき，良 好な結果が得られた。この 2 例に対し, 手術なしで斉 まされたのではないかという反省は残り, 特に 1 例め はその観を強くするが， 2 例めはまだ妊娠可能な年齢 であり, 総合的に判断し, 手術は適切な選択であった と考えている，以上のことから，塞栓術により，破裂 直後の急性の出血がコントロールできれば，破裂後治 療を追加する場合は, 手術は充分な時間をおいて, 炎 症が治まるのを待って行った方が良いと思われる.

一方，破裂のために塞栓術を施行した場合でも，準 緊急的に引き続き手術する選択もあると思われるが, 今回はその経験はなかった。塞栓術が永久治療となら ない可能性が強いのであれば，十分考慮してもよいも のと思われる。

\section{結 語}

10例12腎に発生した腎血管筋脂肪腫の治療経験に基 づき, Oesterling の提唱した治療方針に加え，次のよ
うな筆者らの考えを示した。

1）直径 $4 \mathrm{~cm}$ 以上の AML においては，破裂の危険 が高いため, 塞栓術あるいは核出術によって積極的な 治療が望ましいと思われる。特に結節性硬化症に合併 するような多発性腫瘍においては，症状の有無にかか わらず，積極的治療が望ましいことを痛感した。

2）Collins 液などによる腎 in-situ 灌流方法を用い れば，大きい腫瘍，多発性の腫瘍に対しても，腎保存 手術の適応をより広げる可能性があるため，本法を用 いてのより積極的な外科的治療も考えてよいものと思 われる。

3）AMLの破裂を来した場合は，必要に応じ，塞栓 術で加療し，更に追加手術療法を行う場合には，比較 的長期の観察期間をおいた後，手術することが望まし いと思われる。

\section{文献}

1) Oesterling, J.E., Fisherman, E.K., Goldman, S. M. and Marshall, F.F.: The management of renal angiomyolipoma. J. Urol., 135, 1121$1124,1986$.

2) Masaki, Z., Ichigi, Y., Kuratomi, K., Iguchi, A., Sato, S., Nakamura, K., Hirata, Y., Tokuda, Y. and Nohtomi, T.: In situ perfusion by retrograde cannuration of a tumor artery for nephron-sparing surgery. Internat. J. Urol., 2, 161-165, 1995.

3）高士宗久, 村瀬達良, 山本雅憲, 傍島 健, 三宅弘 治, 三矢英輔, 相馬駛量, 荻原文一, 渡辺丈治, 大 竹 浩：腎血管筋脂肪腫の 3 例一本邦194例の統 計一。泌尿紀要, 30, 65-75, 1984.

4) Rosen, R.J., Schlossberg, P., Roven, S.J. and Rothberg, M.: Management of symptomatic renal angiomyolipomas by embolization. Urol. Radiol., 6, 196-200, 1984.

5）木下博之, 池上元保, 伊東史雄, 曽根淳史, 田中啓 幹：自然破裂を来した腎血管筋脂肪腫の 1 例．泌 尿外科, 7, 701-704, 1994.

6) Zerhouni, E.A., Schellhammer, P., Schaefer, J. C., Drucker, J.R., Jaffe, A.H., Gonzales, J.E., Edwards, O.E. and Lamptom, L.D.: Management of bleeding renal angiomyolipomas by transcatheter embolization following CT diagnosis. Urol. Radiol., 6, 205-209, 1984.

7) Uchino, A., Itoh, K., Egashira, K. and Ohno, M. : Therapeutic embolization for renal angiomyolipoma-Case report and review of the literature. Radiation Medicine, 5, 191-194, 1987.

8）渡辺俊幸, 森本鎭義, 新家俊明, 川端 衛, 佐藤守 
男, 山田龍作：保存的治療として塞栓術を施行し た腎血管筋脂肪腫の 1 例。泌尿紀要，35，11831187, 1989.

9）松久 進，大西洋行，窪田正典，大岡啓二，万波 誠：腎保存手術を施行した腎血管筋脂肪腫の 1 例. 西日泌尿，51，619-622，1989.

10）真崎善二郎, 市木康久, 中牟田誠一, 井口厚司, 小
嶺信一郎, 木下徳雄, 吉田一博, 吉永衛俊, 藤山千 里, 佐藤伸二, 岸川 高, 工藤 祥, 金子邦之, 松 本俊一, 松尾義朋, 原田貞美：鈍的腎外傷の診断と 治療一治療方針決定の要因, 特に CT, 血管造影, 動脈塞栓術について。西日泌尿，51，471-476, 1989.

（1995年10月 6 日受付，1996年 6 月10日受理） 